\title{
Projections for the geopolitical economy of oil after war in Iraq
}

\author{
Paul A. Williams \\ Department of International Relations, Bilkent University, Ankara, Turkey
}

Available online 24 April 2006

\begin{abstract}
How are events surrounding the latest Iraq war shaping the future global political economy of oil? The saliency of Iraq's oil resources suggests a trend towards intensified great-power competition to dominate energy-rich provinces and transportation corridors. Yet, the nature of the oil trade, Iraq's insurrection, and Sino-American economic interdependence indicate barriers to unilateral attempts to control energy supplies. Based on examination of the Iraq conflict's unintended stimulus to terrorism and to China's search for foreign oil supplies, this paper assesses three possible scenarios: 'multiple energy insecurity' (great-power competition and violent non-state reaction); 'mutual energy securitisation' (inter-state collusion against non-state resource claimants); and 'multiple energy security' (great-power curtailment of geographically expansive energy consumption). It finds that the increasing problems associated with the first two alternatives are inducing decision-makers to contemplate policy options consistent with the third scenario.
\end{abstract}

(C) 2006 Elsevier Ltd. All rights reserved.

\section{Overview}

The March 2003 Iraq invasion has been inextricably linked to that country's oil. Detractors posited that the war would allow Western oil companies to bring Iraq's vast hydrocarbon reserves into production, thereby solidifying asset values, lowering oil prices for consumers and attenuating OPEC's market power [1]. Feeding suspicions of the oil-war nexus were remarks by then US Deputy Defence Secretary Paul Wolfowitz before Congress that "The oil revenues of that country could bring between $\$ 50$ billion and $\$ 100$ billion over the ... next two or three years" [2]. Some detect a trend towards more frequent recourse to US exercises of coercion to secure future energy supplies, in a context of

E-mail address: paulw@bilkent.edu.tr. 
increasing worldwide scarcity driven both by rising demand and limited supply. As one author has commented, "Slowly but surely, the US military is being converted into a global oil-protection service" [3, p. 7]. Thus, the first Gulf War and the latest Iraq conflict have revived once-dormant concerns over 'resource war' [3-5] and underscored the resiliency of realist geopolitical thought $[6,7]$.

This analytical purview rarely encompasses examination of the degree of commensurability between force and energy security. The Iraq war has notably strengthened America's military position in the Gulf region without augmenting Iraq's contribution to global energy supplies. A 'three-dimensional chessgame' metaphor of international politics [8, p. 39], indicating the difficulty of converting military pre-eminence into control over outcomes in other dimensions, cautions against predicting energy-motivated incursions elsewhere based on the Iraq case. Raw coercion is proving inapt not only for discriminating among consumers in a fungible market, but also for defending an entire global oil-supply chain offering multiple points of access; therefore, even superpowers pay disproportionately higher prices to prevent, let alone engineer, disruptions.

Below, we discuss the extent to which the Iraq War allows for prognosticating more great-power 'resource wars.' We then analyse three plausible Iraq-centric scenarios impinging on the global political economy of oil. Forming the core of this evaluation, the first scenario, 'multiple energy insecurity,' suggests straight-line extrapolation from the Iraq war towards escalation of energy-oriented Sino-American competition and non-state resistance to great-power forays in local arenas. In a second scenario, US-Chinese economic interdependence supports 'mutual energy securitisation,' where consuming powers collude to suppress non-state movements acting to impede foreign investment. Rising costs in the first scenario and the second's impracticality leave greater space for unfolding of the third scenario, 'multiple energy security,' where consumption trajectories are lowered and local developing-world resource problems are addressed.

\section{Extrapolating from the Iraq conflict}

\subsection{Auguring 'resource war'}

Certain indices point to the weight of energy-related motives in the US government's 2003 decision to occupy Iraq. By 2000, petroleum's contribution to total US energy consumption, in terms of heat content (British thermal units), hovered at two fifths, having declined slightly from 1970 levels, but net oil imports supplied over one-fifth of the 2000 figure, double its proportion 30 years earlier [9, pp. 9-11], and the 2000 figure is expected to increase by another one third by 2025 [10, p. 163]. In the last three decades of the 20th century, total daily US domestic petroleum output, despite a near trebling of refinery processing gains on domestic crude oil, declined by almost three million barrels, while net imports increased by over seven million. In 2000, net imports exceeded half of all oil consumed, then just under 20 million daily barrels, a figure projected to increase to 28 million by 2025. Even if 2000 domestic output can be maintained until 2025, an assumption based on large expected increments to proved reserves and refinery capacity, only a doubling of 2000 net imports can sustain expanded consumption [9, p. 127, 10, pp. 40 and 216]. 
This trend is dominated by the resiliency of transportation's share of energy consumption and its domination of oil imports, largely attributable to the growth of automobile-orientated infrastructure [1]. During 1970-2000, almost exactly in tandem with increases that raised imported oil to one quarter of total energy consumption by heat content (US oil imports have never comprised less than four fifths of total imported energy), transportation, nearly all of its energy consumption requirement met by petroleum, also expanded its share to just over one quarter of total energy usage, although motor gasoline's 70-percent share of the transportation component dropped by seven percent [9, pp. 5 and 38-42 and 159].

Furthermore, Persian Gulf oil's share of the import basket has grown. This portion rose from less than four percent in 1970 to over one fifth in 2000, and is projected to exceed one quarter (previously attained in 1976-1978) by 2025. While the bulk of this share comprises Saudi oil, even Iraq's oil exports to the US grew by over 100fold from 1970 to cover over six percent of total US petroleum imports in both 1990 and 2001 [9, p. 133]. Acknowledging the elusiveness of energy self-sufficiency, post-war US presidents have consistently backed using military force to ensure the flow of Gulf oil. The 1973-2003 period describes a trajectory of increasingly overt intrusions: Nixon's contingency plan to seize Gulf oilfields during the 1973-1974 Arab oil embargo; Reagan's dispatch of naval forces to join a multinational fleet protecting Strait of Hormuz shipping during the 1980-1988 Iran-Iraq War; the senior Bush administration's UN-sanctioned 1991 authorisation of a US-led effort to repel Iraqi forces from Kuwait; and the 2003 US-led, but UN-unsanctioned, invasion of Iraq by the second President Bush.

Division exists on the extent of oil's role in the latter pair of conflicts. If war has both 'permissive' causes that enable it and 'efficient' causes that motivate it [11, pp. 224-238], some, by stressing that the Soviet Union's collapse left no country to balance US power [12, pp. 183-184], relegate oil factors to constant background presence. However, others argue that these conflicts herald a new phase of 'resource war,' implying that 'efficient' causes have become more salient, in line with aforementioned trends and dire forecasts of a 2010 peaking in global oil production [5]. Answering the question of what else should be occurring if the 'resource war' thesis is accurate, some logically seek out evidence of conflict broiling elsewhere in the Gulf region, where two thirds of the world's proved oil reserves are located, and in other significant energy-producing regions [1, pp. 80-101, 3, pp. 74-101], a matter discussed in the context of Scenario one below.

\section{2. 'Oil war' as anomaly}

Other evidence attenuates expectations of a wave of similar wars. While inadequate to reverse declining US domestic oil extraction, post-1973 trends in price deregulation, taxation and stockpiling have conditioned demand growth, output decline, and the impact of supply disruptions. During 1978-1983, before the downward trend stopped, a 20percent drop in oil use lowered overall energy consumption by nearly one tenth and oil imports by nearly two fifths [9, pp. 9 and 127]. Moreover, improved energy efficiency and the shift towards services reduced US energy spending as a share of GDP in 2000 to slightly under 1970 levels while decreasing per-dollar energy consumption by over two fifths $[9$, p. 13]. Countering this general trend is the aforementioned resiliency of 
transportation's energy usage, which the economy's more salient service-sector orientation has promoted.

The 1970s price hikes that attended OPEC members' nationalisation of multinational corporate assets and the Arab embargo have actually enhanced flexibility in the global oil trade. The price rise undermined many producers' interest in setting prices via contract rather than the spot market, thereby reinforcing speculation-induced market volatility, but it also complicated efforts to allocate the burden of collective production restraint [12, pp. 168-169, 13, pp. 179-180, 189-191]. Commodity fungibility, facilitated by arbitrage opportunities and the related capacity to re-direct tanker supplies to exploit them, now renders discriminatory supply cuts ineffectual, as forces of supply 'push' and demand 'pull' exert generalised and uniform impacts on consumer prices [14,15, pp. 54-55]. As a result, for example, real costs to US refiners (in 2000 dollars) of acquiring both domestic and imported crude oil increased from roughly equal levels in 1973 to the equivalent maxima in 1981 before falling in tandem to 1973 levels in 1998 [9, p. 173].

Even if market fungibility lowers the efficacy of oil embargoes and high prices make collective production restraints less sustainable, a two-decade diminution in major oil producers' spare capacity to less than 15 percent of its 1985 peak aggravates the marketrelated effects of supply disruptions, though amplified price volatility spreads through the world economy [16, pp. 3-6]. Yet, since the late 1970s, member countries of the International Energy Agency have amassed oil stockpiles, notably the US Strategic Petroleum Reserve, and agreed to emergency drawdowns [12, p. 202], although political determination of emergency can delay release and thus hasten recession, as occurred after Iraq's 1990 invasion removed Kuwaiti output from the world market, but not when Hurricane Rita impacted key concentrations of US hydrocarbon extraction, refining and transportation in 2005.

America's consumption of one quarter of global energy and oil output, shares projected to decrease only slightly in 2025 [10, pp. 163 and 167], makes oil inextricably part of its Persian Gulf presence (as the assessment of benefits and costs in [17, pp. 93-95] underscores). In 2000, while accounting for 13 percent of US oil supplies, the Gulf provided three tenths of the world's crude oil [9, pp. 127 and 133]. Greater diversification of American oil imports has made many exporting countries relatively more dependent on its markets. While the collective share of its imports from the following countries rose to over two thirds in 2000, the US accounted for nearly one fifth of Saudi exports, one quarter of Iraq's, two fifths of Nigeria's, 46 percent of Mexico's, almost half of Venezuela's and nine tenths of Canada's [9, pp. 133 and 307]. Moreover, while net oil imports comprised one percent of US GDP in 2000, oil revenues ranged from 20 to 60 percent of Venezuelan, Saudi and Iraqi GDPs and over four fifths of their total export earnings [9, pp. 13 and 83, 18, pp. 11-13].

An inapt instrument for supplying particular firms and consuming countries while excluding others, US-launched 'oil war' would more likely stem from efforts to avert globally generalised economic consequences of major supply disruptions. Concern will stay fixed on Saudi Arabia, which possesses 20-25 percent of world proved reserves, produces 12 percent of global oil, and holds most of the world's spare capacity, but the focus will be dominated less by 'voluntary' coordinated cutbacks than by the market's capacity to assimilate 'involuntary' shocks induced by national unrest and non-state terrorism (see below). 


\section{Scenario one: multiple energy insecurity}

\subsection{Non-state violence on the supply side}

The aftermath of March-May 2003 coalition combat operations has yielded mixed results for Iraq's and its oil-sector's recovery. Coalition forces succeeded in protecting the Oil Ministry and oil infrastructure, of which maximum sustainable pre-2003 capacity had fallen below 3 million daily barrels, from wartime damage. Unlike the first Gulf War, when retreating Iraqi forces destroyed 700 Kuwaiti oil wells, the later allied offensive prevented damage to all but seven of Iraq's 1500 wells. Occupation has also stabilised Iraq's oil trade relative to its status during the 1996-2003 U.N. Oil-for-Food Programme. After trebling over a 3-year period, average daily Iraqi exports fell to 1.3 million barrels in the 12 months (March 2002-February 2003) preceding invasion, with monthly standard deviation comprising over one third of the average. During 2004-2005, respective average total and US-bound oil exports rose to 1.5 million and 630,000 daily barrels, albeit at the expense of local consumption, and their greater regularity is indicated by the narrowing of crossmonth standard deviations from over three fifths of 2003-2004 averages to less than 15 percent for the latest period. ${ }^{1}$

Other indicators, however, suggest that war has lessened energy security. Over the first two full-year post-invasion periods (March 2003-February 2005), Iraq's respective average oil output, overall exports and domestic consumption remained, respectively, one quarter, one fifth and 35 percent below average corresponding levels in the six pre-war periods (see footnote 1). In February 2005, output targets were revised downwards by 300,000-600,000 daily barrels to 2.5 million. This has limited Iraq's revenues. By the end of the first 24 months following invasion, the country had accumulated slightly over USD 25 billion in export earnings [20, pp. 23-24], half of the lower bound of Wolfowitz's notional target range. Even these smaller figures incorporate an offsetting boost from higher average perbarrel prices in 2004-2005, due in part to lower exports from Iraq, where instability may have added a USD 10 premium [21].

Post-war constraints on Iraq's output stem largely from an insurrection that has targeted oil-sector activity, especially exports, while also deterring investment needed to restore a deteriorating infrastructure. Through March 2005, Iraqi oil assets had been attacked over 220 times, a number that rose to over 260 by the end of September of that year [22]. The first one in June 2003 shut down the Iraq-Turkey Pipeline, and subsequent strikes have kept its throughput minimal, enforcing a post-war average daily export shortfall of 300,000 barrels. Defending Iraq's pipeline network has diverted more aid and oil receipts towards security, including enlisting the services of tribes, some of whom have engaged in a type of protection racketeering [23,24, p. 76]. However, the 7000-km expanse, surface exposure and dilapidation of Iraq's pipeline network dilute the efficacy of these measures.

Coercive energy security can be counterproductive to the extent that military intervention incurs asymmetrically higher costs per unit of effort than denial of its

\footnotetext{
${ }^{1}$ Monthly data spans from March 1997 to February 2005 inclusive and is arranged into eight equal 12-month periods. Iraqi exports were compiled from all relevant issues of the IEA's monthly Oil Market Report (see address in [15]), while EIA data, applying to US oil imports from Iraq, is assembled from related issues of Monthly Energy Review (see address in [19]).
} 
objectives, which vulnerability of oil-supply lines facilitates. In contrast to assumptions that the revolution in military affairs is shifting the balance of forces towards offensive operations [4], other accounts contend that even overwhelming military power does not confer universal leverage or yield greater benefits. The 'three-dimensional chessgame' metaphor points to the difficulty of translating overwhelming 'top board' military power into favourable outcomes on the 'middle board,' where economic power is more evenly distributed among states, or on the 'bottom board,' where multifarious non-state actors, as in Iraq, exert veto power [8, p. 39]. An analogous concept differentiates commanding 'the commons' (sea, air and space) from victory in 'contested zones,' where otherwise weaker adversaries are advantaged by terrain-based nationalist motivations and home-turf familiarity [25]. In this case, the relatively less costly strategy of denying others their use of seized oil facilities broadens the 'chokepoint' concept to encompass the entire global oilsupply chain, not only its maritime corridors, but also conflict-prone areas traversed by pipelines and worked by oil-sector personnel $[23,26]$.

The Iraq war is metastasising networks of non-state resistance, involving terrorist organisations and local insurrectionists, thus jeopardising long-term global spare production capacity. As Colombia, Chechnya, Iraq, Nigeria and Saudi Arabia attest, violence against oil infrastructure and personnel springs largely from specific grievances, but Al Qaeda operatives can, depending on local circumstances, contextualise these events within their global Islamist struggle. While some hypothesise that a radical group leading an oil-rich country could ramp up output to undercut competitors [13, p. 172], others, citing Osama Bin Laden's 1998 declaration that per-barrel oil prices should be USD 144, suggest that "the strict application of Islamic principles to oil depletion policy should dictate ... a slower rate of extraction that has historically been applied by Saudi Arabia and many other Muslim countries" [1, p. 166]. The October 2002 suicide bombing of a French oil tanker near Yemen, and possibly the failed April 2004 suicide attacks on Iraq's Khor Al-Amaya and Basra oil terminals, drew inspiration from Al Qaeda's targeting of "the provision line and the feeding artery of ... the crusader nation" [27, p. 64]. Although an estimated 6 percent of the Iraqi resistance in February 2005 comprised 'foreign fighters' [20, p. 15], Jordanian-born combatant Abu Musab al-Zarqawi claimed in December 2004 to have been following Bin Laden's orders to detonate a pipeline supplying refined products to Baghdad [22].

The exigency of restoring oil infrastructure highlights the critical role of foreign companies and contractors, which has led terrorists to extend the corresponding ambit of their operations. Though paling in comparison to the 14,000-24,000 Iraqi non-crimerelated casualties since war's start [20, pp. 9-13], the killing of foreign contractors and Iraqi personnel impedes oil industry's rehabilitation. Shortly prior to the April 2004 attack on Iraq's oil terminals, an internet posting attributable to Al-Qaeda's presumed leader in Saudi Arabia stated that, "Strikes on oil wells and pipelines in Iraq may lead to the withdrawal of foreign companies or at least destroy the security and stability needed by them to plunder the wealth of Muslims" [28].

Similar problems afflict Saudi Arabia. Investment there is needed simply to sustain existing production levels, let alone expand OPEC's dwindling spare capacity. By early 2005, OPEC's collective capacity expansion had barely offset respective declines from Indonesia and Venezuela, and a plurality of this increase originated in Saudi Arabia, where state oil company Aramco boosted capacity enough to reach a maximum sustainable production capacity of 10-10.5 million daily barrels [29, pp. 12-14]. In line with IEA 
estimates that its production has to double to meet forecasted 2020 world demand, the Saudi government has pledged to raise capacity to 15 million daily barrels by 2020 [30].

Even capacity maintenance presents problems. The aforementioned expansion has merely arrested a significant annual decline in older fields, with 'supergiant' Ghawar, which produces half of Saudi crude, nearing its peak of production, indicated by increasing reliance on costly water-injection recovery techniques [29, pp. 6-10, 30,31, p. 14]. This issue is not entirely inseparable from security problems. The Saudi kingdom's internal opponents seek to sabotage oil operations, as in the summer 2002 attempt against Ras Tanura, the world's largest offshore oil-loading facility. The government spends large sums on internal security. However, resentment at the Western presence in Iraq has provoked terrorism against foreign civilians, as occurred in May 2003 and 2004 incidents, raising the difficulty of recruiting the necessary expertise to expand future output capacity.

\subsection{Geopolitical apprehensions over Chinese demand}

Although this strategy did not commence with the Iraq war, the latter conflict seems to have intensified China's search for non-Persian Gulf oil. Its economy grew by nearly 10 percent per annum during 1977-2001 and is projected to continue expanding at 6 percent over the 2001-2025 period, after which time Chinese GDP may trail only those of the America and Japan [10, pp. 17-22]. Between 1990 and 2000, Chinese energy consumption rose by over one third, equalling approximately one fifth of the world increase, and is forecasted to rise by another 146 percent until 2025, accounting for almost one quarter of the global increment. Similarly, in the 1990s, oil consumption doubled, the increase comprising over one fifth of global expansion, and, by 2025, it is projected to rise by another 167 percent, making up just under one fifth of world growth [10, pp. 163 and 167]. During 1999-2004 alone, Chinese consumption grew by half, accounting for one third of the global increase, to reach 6.4 million barrels [32, pp. 5-6]. A 20-percent yearly expansion in automobile ownership could help China surpass the United States in number of cars by 2030, but larger transportation energy use, growing from 10 to 15 percent of total usage over 2001-2025, will consume 5 million daily barrels, two-thirds of China's additional oil demand [10, pp. 29-32 and 163-167].

From 1993, when it first became a net oil importer, until 2004, when it was importing oil to meet just under half of its demand, Middle Eastern crude oil came to fill more space in its import basket. In 1993, China obtained slightly over two fifths of its crude oil imports from the Middle East, the same share as from its Asia-Pacific neighbours, but 6 years later, China was taking just under one half of imports from the Middle East, with Oman remaining the largest of its Middle East suppliers, followed by Yemen, Iran and Saudi Arabia [33, pp. 125-126]. In the early part of this century, the Middle East provided 45 percent of China's oil imports, a share projected to rise to two thirds by 2025, from 900,000 to 5.7 million daily barrels [10, p. 40], in line with increased transportation uses.

This forecasted expansion, specifically of Persian Gulf oil imports, belies the notion that the Iraq War will have lasting effects on China's overseas oil activity. However, the run-up to war most probably stimulated a jump in precautionary stock-building: China's apparent oil demand rose to an unprecedented monthly average high of 5.52 million daily barrels in January 2003, while net crude oil and total oil imports also peaked, registering their largest year-on-year and monthly gains until then [34, pp. 12 and 31]. This appears to have dovetailed with the government's February 2003 decision to create by 2005 a strategic 
petroleum reserve holding 1 month's national supply [35], although this idea originated in the Tenth 5-Year Energy Plan (2001-2005) and acquired added impetus after the US military campaign in Afghanistan [36, pp. 52-53].

The extent to which China is limiting its dependence on Middle Eastern oil is uncertain. Oil companies of China, never a significant importer of Iraq's oil, agreed in June 1997 to develop Iraq's al-Ahdab field to produce 90,000 daily barrels; however, this represented a minor fraction of the contracts to augment Iraq's output by 4.7 million daily barrels, and the risk of losing this investment, which may have occurred in June 2003 [37, pp. 10-11], constrained Sino-Iraqi interaction. During 2003-2004, China reduced its use of Middle Eastern crude, from half to 45 percent of total imports, and within that basket, increased imports from Oman while decreasing those from Saudi Arabia and Iran, although the latter's government concluded a notable October 2004 deal whereby a Chinese company will buy liquefied natural gas (LNG) and develop the Yadavaran oilfield in exchange for importing another 150,000 daily barrels of Iranian oil over the next 25 years [38, pp. 28-29].

Broader caution about expanding Persian Gulf oil importation reflects Chinese awareness that the Strait of Hormuz serves as egress for 15 million daily barrels of oil, of which 11 million, constituting one quarter of world trade and the source of three fifths of China's oil, ply the pirate-infested waters of the Straits of Malacca on their way to East Asia [26, pp. 8-9, 27, p. 67]. Interest in bypassing the latter waterway is reflected in proposals to build a trans-Myanmar pipeline or a canal crossing Thailand's Kra Isthmus, and in the construction of an oil-tanker harbour in Gwadar, Pakistan, which could eventually permit Persian Gulf oil to reach China via complementary overland links connecting Karachi to Xinjiang [39, pp. 5-7]. However, these measures do not allay China's fear that "its most important source of petroleum imports, the Persian Gulf area, lies at the end of very long sea lanes of communication (SLOCs) that are dominated by the navy of a potential enemy" [36, p. 66]. As one Chinese (state) oil company source asserted, "it is very important for China to establish an onshore oil import channel" [40].

Consequently, China has adjusted its sights closer to home. Russian company Yukos had been supplying most of China's Russian oil imports via rail, which increased from nearly six to nine percent of China's total import basket during 2003-2004 [38, p. 28], and agreed in June 2003 to construct a $2400-\mathrm{km}$ pipeline to carry Siberian crude from Irkutsk to Daqing, China's large but maturing oil province. Although the Putin administration later confiscated and sold off this company to pliable state outfits and tussles have occurred over whether the pipeline should extend to China or to a Pacific port nearer to Japan, plans to build an initial pipeline spur in China's direction suggest prioritisation of Daqing [35,41].

China has also intensified its Kazakhstan activity, beginning with the 1997 purchase of a 60-percent share of Aktobemunaigaz company and ancillary rights to develop two oilfields in return for building a 3000-km pipeline linking Aktyubinsk to Xinjiang. Completed in 2003, the first section connects the Aktobe field to oil hub Atyrau, and in September 2004, work began on a longer trunk line connecting Atasu to Xinjiang, where 200,000-400,000 daily barrels, meeting about 5 per cent of China's 2006 oil demand, will be refined and shipped via an easterly artery paralleling the West-East natural gas pipeline to China's coast $[35,42]$. Astana, which has been shipping almost one quarter of its exports westward by barge from Aktau across the Caspian Sea to Azerbaijan and is seeking to raise port capacity to 800,000 daily barrels, has interests in ensuring the success of the Sino-Kazakh 
pipeline, related not only to its chances of obtaining more favourable terms for exporting oil westwards via the US-backed Baku-Tbilisi-Ceyhan (BTC) pipeline [43-45], but also to Kazakhstan's dependence on trans-China flow of Irtysh River water for hydropower, now accounting for one fifth of Kazakhstan's electricity generation [42, p. 9].

Indeed, the Caspian region could emerge as a battleground on which foreign oil companies carry out their respective parent governments' national interests. Chinese oil major lie under State Council auspices [36, p. 4], permitting commercially questionable decisions like CNPC's aforementioned 1997 Kazakh purchases. After August 2003, CNPC increased ownership of Kazakhstan's North Buzachi oilfields and, 2 years later, bid USD 4 billion for Canada's PetroKazakhstan and its fields [43,46]. The US government's quashing of China National Offshore Oil Corporation's (CNOOC) bid allowed rival Chevron-Texaco, owner of half of the Tengiz field and 15 percent of the Caspian Pipeline Consortium (CPC) pumping its oil to Russia's Novorossiisk Port, to buy US company Unocal's 1/10th share of Azerbaijan's offshore Azeri-Chirag-Guneshli output and its 9percent share of the BTC pipeline [47]. Compounding larger concerns, including Beijing's suspected efforts to obtain dual-use underwater terrain-mapping technology [36, p. 71, 48], CNOOC's bid raised the spectre, which Chevron-Texaco exploited, that "over time, oil will be diverted to China on a non-commercial basis" [50, p. 69].

Beijing's oil search may encroach on traditionally US-orientated exporting regions. In 2003-2004, the share of Chinese imports from Africa rose to 28 percent, and, while the Sudanese proportion decreased slightly, the share from Angola, which was sending nearly one quarter of its oil exports to China by 2001, rose to 13 percent in 2004 [38, pp. 28-29]. In Canada, Alberta province's expansive tar sands deposits, where oil extraction is economical only at USD 30 per barrel, generate a volume (capable of trebling by 2015) equal to one third of Canada's total, most of it exported southward [51,52], where, by NAFTA's terms, it has to continue [1, pp. 82-83]. Nonetheless, Chinese companies have sought to help Canadian firm Enbridge to build a pipeline to deliver upgraded bitumen oil to British Columbian ports and assist Trans-Mountain pipeline-operator Terasen in expanding this westerly pipeline's capacity and supplying oil tankers to defray Chinese refiners' cost of test-processing synthetic crude [38, pp. 30-31, 51, 52]. Resulting trade could divert one third of Canada's exports eastwards [53].

Chinese inroads into Latin America, notably Venezuela, are also deepening. Holding the Western Hemisphere's largest proven conventional oil reserves of 77 billion barrels, but probably experiencing a permanent loss of 400,000 daily barrels as a result of a December 2002 strike, not from OPEC-related output cuts, Venezuela has advanced up US policy agendas. Worsening US-Venezuelan relations is advantaging China. In late 2001, CNPC, PetroChina and PdVSA joined on a project to produce high-quality synthetic Orimulsion fuel that reportedly got underway in April 2004, and began building a complementary Orimulsion-fired power plant in China in November 2003 [69], matching Venezuelan plans to double Orimulsion capacity to boost East Asian sales. President Hugo Chavez's 2004 visit to Beijing resulted in a Chinese agreement to develop 15 eastern Venezuelan oilfields, build refineries there and import fuel oil, complementing trilateral plans to build a transColumbian pipeline by-passing the Panama Canal [49,54]. This partially substantiates Chavez's 2004 statement that "now we are free and ... make our resources available to the great country of China" [53]. The potential future importance of these supplies in China's oil-import basket may challenge the basis for the conventional geopolitical inference that "what happens in South America does not matter very much to US citizens" [6, p. 258]. 


\subsection{Chinese oil and terrorism}

On the other hand, this scenario also consists of China's geographically expansive search for energy supplies, as it has for the US, confronting non-state actors seeking to resist these forays. This could affect the supply of oil reaching, originating in, or leaving China's northwest Xinjiang Uighur Autonomous Region. Including the Sino-Kazakh pipeline and the overland route originating in Pakistan, projects involving Xinjiang fit into a larger 1996 Chinese oil-industry scheme that depends on enticing foreign companies to invest in developing both the Taklamakan Desert's Tarim Basin in Xinjiang, where 144 million barrels was reportedly extracted in 2002, and in building a 4000-km eastwards pipeline from there to Shanghai [36, pp. 21-25].

The military presence in the project area suggests an abiding concern to suppress opposition to these projects that could actually catalyse it. Given the possibility that Turkic separatists opposed to its 'Hanification' will target Xinjiang's dense energyinfrastructure array, the West-East natural gas pipeline (much like the BTC pipeline pumping Azeri oil to Turkey's Ceyhan Port) is being buried underground [36, p. 62], and Xinjiang has emerged as the People Liberation Army's (PLA) premier centre for testing new warfare tactics and equipment and has hosted joint Sino-Pakistani counter-terrorism exercises [55]. Chinese contractors remain vulnerable in Pakistan, as construction of the aforementioned Gwadar-Xinjiang overland passageway has catalysed oppositional networks drawing both from displaced Uighur Turk populations residing in Pakistan, where the Eastern Turkestan Islamic Movement's (ETIM) erstwhile head was killed, and Baluch nationalists who have kidnapped and killed several Chinese project engineers [56, pp. 7-8].

\section{Scenario two: mutual energy securitisation}

Relative-gains thinking characterising certain realms of interaction may not intensify great-power conflict when absolute gains from larger mutual interdependence outweigh them [57, p. 123]. In this scenario, economic growth underlying increases in China's imported oil demand may even reinforce an overarching Sino-American interdependence that promotes in oil-interest convergence. China has been running a USD 150-billion-plus trade surplus with the US, leading the latter to threaten import protections, permitted to an extent under the terms of China's 2001 WTO accession, and pressure Beijing to raise its currency value. Yet, the latter's willingness to cover US deficit-financing of imported goods by investing over USD 700 billion of foreign exchange reserves in US securities returns a stream of benefits to the US [58,pp. 12-16, 59] that allow it to purchase high-priced imported oil.

Some oil interests, however, are inherently mutual. Although Beijing has been directing Chinese oil firms to acquire overseas assets since the ninth 5-Year Plan (1996-2000), it also seeks to attract foreign investment. A 1998 corporate re-organisation allowed CNPC's subsidiary PetroChina, Sinopec and CNOOC to raise over USD 6.5 billion in stock, giving British Petroleum a one-fifth stake in PetroChina and, along with ExxonMobil and Shell, part of a 15-percent minority share in Sinopec, while resulting in Shell's USD 200-million purchase of CNOOC shares [35]. By 1997, the government was opening large swatches of land, including Tarim Basin, to foreign investors, resulting in USD 770 million in signed contracts with 35 companies; 6 years later, it was inviting outside firms to develop the 
West-East natural gas pipeline [36, pp. 23-24, 45]. Offshore oil has been supplying 1/10th of China's output, largely on the strength of drilling work by outside firms, including Chevron-Texaco, the rival bidder for Unocal, which, together with Shell, withdrew from the CNOOC-led East China Sea project, depriving CNOOC of needed deepwater exploration technology and expertise [60].

As long as China essentially pays for US purchases of its own goods, the US military will be less amenable, even if it could, to cutting fuel supplies than to collaborating to suppress non-state sources of supply disruption. The aforementioned willingness of Chinese companies to invest in Iran, Beijing's cooperative gestures towards Washington over Iraq, including pledges of reconstruction aid, signing Security Council Resolution 1546 to approve stationing US-led multinational forces and re-opening its Baghdad embassy [61], and China's dilatory backing of ASEAN's anti-piracy centre [36, p. 65], imply that Chinese leaders will continue to calculate a highly unfavourable cost-benefit ratio in substituting for provision of sea-lane safety and Gulf stability [33, p. 135].

Indeed, China and the United States could have a mutual interest in 'securitisation' of energy supplies, depicting non-state resistance "as an existential threat, requiring emergency procedures and justifying actions outside the normal bounds of political procedure"' [62, pp. 23-24]. In 2002, when his government was lifting restrictions on official aid and funding counter-terrorism efforts in two BTC countries, Azerbaijan and Georgia, US State Department official Richard Armitage visited Beijing, where he supported classifying the Uighur ETIM as terrorist [36, p. 58]. Yet, this example also highlights inherent practical limits to this strategy, given China's preferences for cooperating with its Russia and Central Asian partners in the anti-Islamist, albeit anti-democratic, Shanghai Cooperation Organisation (SCO). Calls for investigation into Tashkent's violent 2005 crackdown on dissent influenced SCO's request for a deadline to be set for US military withdrawal from member territories and Tashkent's decision to close American bases [63].

\section{Scenario three: multiple energy security}

In this case, the energy-consuming powers take action to lower (geographically) expansive consumption profiles, thereby also widening potential space for local resource claims to be addressed. This anti-geopolitical economy of oil would seem unlikely to materialise except for the mounting difficulties associated with the previous two scenarios. This scenario features reduction of US and Chinese domestic energy consumption, especially in the transportation sector, via market-governed regulation (i.e., rationalisation of subsidies and raising of gasoline taxes), higher energy-use efficiency and technological innovation, transfer of which US and Chinese membership in the World Trade Organisation (WTO) could facilitate. In some circumstances, however, environmental problems could worsen.

As previously indicated, increasing oil imports are directly attributable to higher levels of personal access to motor transport. Post-1973 enhancements in US corporate average fuel efficiency (CAFE), applicable to passenger vehicles and achievable only under ideal driving conditions, peaked at 8 litres/100 km (27.5 miles per gallon, or mpg) in 1987, when lower oil prices enabled a resurgence of Persian Gulf Oil imports to meet an expanding proportion of sales comprised by larger passenger vehicles (attaining less than $20 \mathrm{mpg}$ ), which meet lower CAFE standards and even receive large tax credits [17,64, p. 25]. Actual mean fuel-efficiency rates of all US motor vehicles increased by over one quarter between 
1973 and 1987, but only by 12 percent over the 1987-2000 period, attaining 17 mpg in 2000 [9, p. 57]. Moreover, moving a single passenger consumes nearly 98 percent of the original oil extracted to run the car [65, p. 57]. Chinese fuel consumption per kilometre exceeds developed-country levels by $10-20$ percent [10, pp. 32-33].

Trends suggest that higher oil prices reflect, and have been advancing, shifts in energy consumption. At one level, rising prices reflect stronger environmental concerns, thereby promoting increased consumption of relatively scarcer supplies of less sulphuric crude-oil blends, which also exerts demand 'pull' on the more sour blends via the concomitantly higher profit margins associated with tailoring fuel qualities to meet stringent emission standards. However, this in turn is straining extant refinery capacity, its expansion potential already constrained by future profit-margin uncertainty and siting restrictions, supporting OPEC officials' assertions that high prices are less attributable to overall lack of crude supplies than to a refinery shortage [66], especially in the US, where, although average per-refinery capacity increased almost 150 percent during 1970-2000, number of refineries decreased by over two fifths [9, p. 143].

Regardless of their cause, higher oil prices and their perceived geopolitical ramifications are nonetheless altering energy-use patterns. Even if lack of political will precludes gasoline tax hikes in China and the US (where respective 2000 retail prices were one third and two fifths of Japan's), which could help raise their rates to the latter's 35-mpg. standard [9, p. 313,17, p. 207], lower large-vehicle sales rates and increased purchases of more fuelefficient vehicles reflect growing influence of a coalition, joining otherwise disparate groups of environmentalists, religious conservatives and geo-strategists, that favours radically improving transportation's energy efficiency. Their strategy centres on wider incorporation of available technology, like 'plug-in' capacity for hybrid electric vehicles, which could reduce gasoline consumption by 85 percent while doubling existing fuel efficiency to $100 \mathrm{mpg}$, and flexible-fuel modifications, which, if supplementing 'plug-in' features, could raise fuel efficiency by another magnitude of five. These would lower 2025-projected expansion of US oil imports by nearly 8 million daily barrels, capping volumes near current levels [67].

The key potential trade-off inherent in this strategy lies in the need to generate more electricity, which relies mostly on coal burning. China and the US, respectively posses over $1 / 10$ th and one quarter of the world's proven coal reserves and generate four fifths and three fifths of their electrical power from coal, but there exist no practical means of sequestering most of coal's carbon dioxide emissions [10, pp. 76-77, 17, p. 232]. Trends project US and Chinese respective coal consumption to rise by two fifths and three quarters over the 2000-2025 period, accounting for one fifth and three fifths of world growth and equalling one fifth and over one third of the world's total 2025 consumption, while respective coal-based carbon dioxide emissions are expected to increase by two fifths and 114 percent, comprising nearly similar shares of world growth (nearly one third of total emissions growth) and the 2025 world total [10, pp. 169-175].

These forecasts suggest barriers to increasing general levels of compliance with the 2012 emission-reduction targets entailed in Kyoto Protocol's Annex One, which neither the US nor China has signed [10, p. 42, 36, p. 76]. Yet, efforts to raise the 20-25 percent share of Chinese coal supply that is washed could exacerbate water shortages that may be raising the conflict profile of Chinese upstream uses on international rivers, but this problem and related transportation bottlenecks might otherwise be alleviated via rail-system improvements, coal-slurry pipelines, coal liquefaction and gasification and collocating power 
plants near mines [36, p. 9]. At any rate, it underscores the potential power of Chinese coal use to veto the attainment of stricter global environmental standards.

\section{Conclusion}

Reducing geographically expansive oil consumption could yield multiple benefits running the gamut of geopolitical, economic and even the environmental concerns, if adherence to higher emission-reduction standards compels the implementation of less wasteful processes. None of these outcomes are preordained by extrapolating from present trajectories and they may even contradict each other at some level. Yet, events consistent with an unfolding of the third scenario could allow for considering how to boost minimum per-capita levels of energy use to a level that might allow for more sustainable population growth rates in the developing world, which accounts for a rising share of energy use and emissions. Compared to developed-world counterparts, the average user in developing nations consumes less than one fifth, corresponding to a quantity considered to be an important development threshold [65, p. 38]. One manifestation of this problem is exemplified in the case of Iraq, where post-invasion domestic oil consumption has fallen by over one third, and even in China, where mean per-capita energy use is $1 / 15$ th that of the US. Suggesting available room for reform, corrective measures will probably include efforts to rationalise price structures and increase incentives for reducing smuggling of refined products and raising domestic output and usage efficiency, problems afflicting most of the developing world including Iraq and China [24,68]. Nonetheless, lowering the geopolitical profile of imported energy-supply races will aid in increasing the political saliency and urgency of these domestic market-oriented measures.

\section{Acknowledgements}

I thank Ali Tekin and two anonymous reviewers for their helpful comments on an earlier version of this paper.

\section{References}

[1] I. Rutledge, Addicted to oil: America's relentless drive for energy security, I.B. Tauris, London, 2005.

[2] J. Gerth, Report offered bleak outlook about Iraq oil, New York Times, 5 October 2003, Available at: www.nytimes.com/2003/10/05/international/middleeast/05OIL.html.

[3] M.T. Klare, Blood and oil: the dangers and consequences of America's growing dependency on imported petroleum, Metropolitan Books, New York, 2004.

[4] J. Orme, The utility of force in a world of scarcity, International Security 22 (3) (19971998) $138-167$.

[5] S. Peters, Coercive western energy security strategies: "Resource wars" as a new threat to global security, Geopolitics 9 (1) (2004) 187-212.

[6] C. Gray, The continued primacy of geography, Orbis 40 (2) (1996) 247-259.

[7] M. Klare, The new geopolitics, The Monthly Review 55 (3) (2003) 51-56.

[8] J. Nye, The paradox of American power: why the world's only superpower can't go it alone, Oxford University Press, Oxford, 2002.

[9] Energy Information Administration (EIA), Annual Energy Review 2004, Available at: www.eia.doe.gov/ emeu/aer/pdf/aer.pdf.

[10] EIA, International energy outlook 2004, Available at: www.eia.doe.gov/oiaf/archive/ieo04/download.html.

[11] K. Waltz, Man, the state and war: a theoretical analysis, Columbia University Press, New York, 1959.

[12] J. Mitchell, et al., The new economy of oil: impacts on business, geopolitics and society, Earthscan Publications, London, 2000. 
[13] L. Maugeri, Not in oil's name, Foreign Affairs 82 (4) (2003) 165-174.

[14] I. Bruce, Why Arab countries can no longer hold western countries to ransom, AGOC, 3 May 2002, Available at: www.gasandoil.com/goc/news/ntm21812.html.

[15] IEA, A user's guide to the IEA Oil Market Report, 11 August 2003, Available at: http://omrpublic.iea.org/ omrarchive/sup2003.pdf.

[16] V. Vaitheeswaran, Oil in troubled waters: a survey of oil, The Economist, 30 April 2005.

[17] V. Smil, Energy at the crossroads: global perspectives and uncertainties, The MIT Press, Cambridge, MA, 2003.

[18] OPEC, Annual statistical bulletin 2004, Available at: www.opec.org/library/Annual\%20Statistical\%20 Bulletin/pdf/ASB2004.pdf.

[19] EIA, Monthly Energy Review, Available at: http://tonto.eia.doe.gov/FTPROOT/monthlyhistory.html.

[20] M. O'Hanlon, Iraq Index: Tracking Variables of Reconstruction \& Security in Post-Saddam Iraq, Brookings Institution, 5 May 2005, Available at: www.brookings.edu/dybdocroot/fp/saban/iraq/index.pdf.

[21] J. Roberts, The costs of Iraqi oil, Platts, Available at: www.platts.com/Oil/Resources/News\%20Features/ Iraq/costs.html, accessed 14 November 2004.

[22] Institute for the Analysis of Global Security (IAGS), Iraq Pipeline Watch, Available at: www.iags.org/ iraqpipelinewatch.htm.

[23] G. Luft, Pipeline sabotage is terrorist's weapon of choice, Energy Security, 28 March 2005, Available at: www.iags.org/n0328051.htm.

[24] Oil, oil everywhere, The Economist, 18 December 2004.

[25] B. Posen, Command of the commons: the military foundations of US hegemony,, International Security 28 (1) (2003) 5-46.

[26] EIA, World oil transit "chokepoints" country analysis brief, Available at: www.eia.doe.gov/emeu/cabs/ choke.html.

[27] G. Luft, A. Korin, Terrorism goes to sea, Foreign Affairs 83 (6) (2004) 61-71.

[28] S. Sachs, Attacks in mideast raise fear of more at oil installations, New York Times, 8 May 2004, Available at: www.nytimes.com/2004/05/08/business/worldbusiness/08oil.html.

[29] IEA, Oil Market Report, 10 February 2005, Available at: http://omrpublic.iea.org/omrarchive/10feb05full. pdf.

[30] J. Gerth, Forecast of rising oil demand challenges tired Saudi fields, New York Times, 24 February 2004, Available at: www.nytimes.com/2003/10/05/international/middleeast/05OIL.html, accessed 24 February 2004.

[31] EIA, Saudi Arabia country analysis brief, Available at: www.eia.doe.gov/emeu/cabs/Saudi.html.

[32] IEA, Oil Market Report, 11 May 2005, Available at: http://omrpublic.iea.org/omrarchive/11may05Full.org.

[33] X. Xu, China and the Middle East: cross-investment in the energy sector, Middle East Policy 7 (3) (2000) $122-135$.

[34] International Energy Agency (IEA), Oil Market Report, 10 April 2003, Available at: http://omrpublic. iea.org/omrarchive/10apr03full.pdf

[35] EIA, China country analysis brief, Available at: wwwr.eia.doe.gov/emeu/cabs/china.html.

[36] B.D. Cole, "Oil for the lamps of China?"-Beijing's 21st-century search for energy, McNair Paper 67 (2003), Available at: www.ndu.edu/inss/menair/menair67/198_428.McNair.pdf.

[37] EIA, Iraq country analysis brief, Available at: www.eia.doe.gov/emeu/cabs/iraq.html.

[38] D. Zweig, B. Jianhai, China's global hunt for energy, Foreign Affairs 84 (5) (2005) 25-38.

[39] China: Myanmar pipeline to secure oil supplies, Global Pipeline Monthly 1(1) (2005), Available at: www.gasandoil.com/gpm, accessed 20 May 2005.

[40] Xinhua, Construction on Sino-Kazakh oil pipeline starts, Alexander's Gas \& Oil Connections, 28 October 2004, Available at: www.gasandoil.com/goc/news/ntc44365.htm.

[41] Associated Press, Russia puts oil shipments to China up by 28\%, AGOC, 17 August 2005, Available at: www.gasandoil.com/goc/news/nts53373.htm.

[42] EIA, Kazakhstan country analysis brief, Available at: www.eia.doe.gov/emeu/cabs/kazak.html.

[43] Asia Times Online, Kazakhstan not afraid to look to China, Alexander's Gas \& Oil Connections [AGOC], 25 March 2004, Available at: www.gasandoil.com/goc/news/ntc41270.htm.

[44] Dow Jones, Kazakhstan considers construction of new Caspian oil terminal, AGOC, 26 May 2005, Available at: www.gasandoil.com/goc/company/cnc52127.htm.

[45] People's Daily Online, China starts work on Kazakhstan-China oil pipeline, AGOC, 20 April 2005, Available at: www.gasandoil.com/goc/company/cnc51614.htm. 
[46] J. Moore, China's Kazakh prize: the expert opinion, AGOC, 15 September 2005, available at: www.gasandoil.com/goc/company/cnc53777.html.

[47] C. Helman, Chevron Texaco-Unocal merger is all about Azerbaijan, AGOC, 20 April 2005, Available at: www.gasandoil.com/goc/company/cnc51610.htm.

[48] S. Lohr, Unocal bid opens up new issues of security, New York Times, 13 July 2005, Available at: www.tuscaloosanews.com/apps/phcs.dll/article?AID = /2005713/ZNYT01/507130370.

[49] C. Buckley, Venezuela agrees to export oil and gas to China, New York Times, 28 December 2004, Available at: www.nytimes.com/2004/12/28/business/worldbusiness/28energy.html.

[50] The Dragon Tucks In, The Economist, 2 July 2005.

[51] EIA, Canada country analysis brief, Available at: www.eia.doe.gov/emeu/cabs/Canada.html.

[52] S. Romero, China in line as US rival for Canada oil, New York Times, 23 December 2004, Available at: www.nytimes.com/2004/12/23/business/worldbusiness/23canada.html.

[53] G. Luft, In search of crude China goes to the Americas, Energy Security, 18 January 2005, Available at: www.iags.org/n0118041.htm.

[54] D. Morris, China: from one threat to another, Star Tribune, 27 March 2005, Available at: www.startribune.com/stories/535/5311910.html.

[55] M. Andrew, Beijing's growing security dilemma in Xinjiang, China Brief 5 (13) (2005) Available at: www.jamestown.org/images/pdf/cb_005_013.pdf.

[56] T. Niazi, Gwadar: China's naval outpost on the Indian Ocean, China Brief 5 (4) (2005) Available at www.jamestown.org/images/pdf/cb_005_004.pdf.

[57] C. Fettweis, Revisiting MacKinder and Angell: the obsolescence of great power politics, Comparative Strategy 22 (2003) 109-129.

[58] Z.M. Beddoes, The great thrift shift: a survey of the world economy, The Economist, 24 September 2005.

[59] D. Levey, S.S. Brown, The overstretch myth, Foreign Affairs 84 (2) (2005) 2-7.

[60] J. Kahn, Behind China's bid for Unocal: a costly quest for energy control, New York Times, 27 June 2005, Available at: www.nytimes.com/2005/06/27/business/worldbusiness/27energy.html.

[61] Y. Mao, Beijing's two-pronged Iraq policy, China Brief 5 (12) (2005) Available at www.jamestown.org/ images/pdf/cb_005_012.pdf.

[62] B. Buzan, O. Waever, J. de Wilde, Security: a new framework for analysis, Lynne Rienner, Boulder and London, 1998.

[63] S. Blagov, The geopolitical balance in Central Asia tilts toward Russia, AGOC, 17 August 2005, Available at: www.gasandoil.com/goc/news/ntc53363.htm.

[64] M. Shiels, Environment drives hummer vs. hybrid row, BBC News, 1 June 2004, Available at: http:// news.bbc.co.uk/go/pr/fr/-/h/business3749377.stm.

[65] J. Sheffield, Future world energy needs and resources, in: R. Bent, L. Orr, R. Baker (Eds.), Science, policy, and the pursuit of sustainability, Island Press, Washington, DC, 2002.

[66] PetroEnergy Information Network, OPEC calls for greater refinery capacity to relieve bottlenecks, AGOC, 9 June 2005, Available at: www.gasandoil.com/goc/news/ntm52351.htm.

[67] "Set America free": a blueprint for US energy security, Set America free, Available at: www.setamericafree. org/blueprint.pdf.

[68] Oilholics, The Economist, 27 August 2005.

[69] EIA, Venezuela country analysis brief, Available at: www.eia.doe.gov/emeu/cabs/venez.html. 